\title{
STUDENTS' PERCEPTION ON THE USE OF MIND MAPPING APPLICATION SOFTWARE IN LEARNING WRITING
}

\author{
Rahmad Fadillah ${ }^{1}$ \\ Pondok Pesantren Anshor al Sunnah Riau. ${ }^{1}$; \\ rahmadfadillah94@gmail.com
}

\begin{abstract}
The aim of this research is to investigate the students' perception on the use of Mind Mapping in learning writing. Mixed method was employed to describe the students' perception on the use of Mind Mapping in learning writing and the advantages and disadvantages of Mind Mapping in learning writing. The researcher took class B who joined writing IV class in academic years 2014 as the research subjects. This research used questionnaire and interview as the instruments for collecting the data. Moreover, The research findings showed that there were positive and negative perception on the use of Mind Mapping in learning writing. The majority of the students had positive perception on the use of Mind Mapping in learning writing and they perceived that Mind Mapping is an effective way to help them to organize the ideas in learning writing. Furthermore, the use of Mind Mapping in learning writing gives three advantages, namely: (1) Mind Mapping eased the students to think and organize their ideas before writing something; (2) it facilitated the students to develop their ideas and (3) it helped the students remember better about the ideas. The findings also showed two disadvantages, namely: (1) Mind Mapping took longer time to create and organize the ideas; and (2) it needed computer access to create a Mind Mapping.
\end{abstract}

Keyword: Perception, Learning Writing, Mind Mapping.

\section{INTRODUCTION}

English is the most commonly used language to communicate and also to interact with people around the world when they come to different countries. Thus, by learning English, the learners have many opportunities to compete in every country in the world which is useful before and after graduating from university. According to Adelabu (2013), because English can be understood and spoken by most people around the world, students should learn English well.

Furthermore, it is commonly known that writing is one of the language skills that also must be taught at university. Writing has been widely regarded as a crucially essential skill in the teaching and learning of English. Harmer (1998) stated that writing is important because it is a basic language skill that should be mastered by the students. The importance of writing skill can be seen not only on students' academic performance but also in the job opportunities. Another fact is stated by Muslim (2014) who stated that in learning process, the students who have good writing skill got higher score then who are unskilled. Therefore, writing should be taught, learned, and practiced in the beginning of learning. In other words, writing should get more attention

CELTIC: A Journal of Culture, English Language Teaching, Literature \& Linguistics

ISSN: 2356-0401, E-ISSN: 2621-9158, VOL. 6, NO. 1, June 2019. 
in the teaching and learning of English in order to prepare the learners to deal with the real communicative life situation. It was supported by Kuihara, Hawken and Graham (2009) who claims that writing is an important tool for educational, occupational and social success.

Writing is one of productive skill which is the most difficult for the learners. It becomes difficult especially in writing for a second and foreign language. Therefore, there are varieties of problems and difficulties in the learning of writing faced by the students. A previous study about the English writing proficiency at academic level conducted by Miftah (2010) found that many students did not know how to generate and organize some ideas for writing a topic. It is supported by Kusmiana (2013) who found that many students had limited ideas to develop a topic for their composition.

Mind mapping is one of popular strategy which is developed by Tony Buzan. The student's need a strategy to help them in the learning writing process. The strategy is also needed to improve and develop students' idea in learning writing. Mind mapping strategy makes the students' easy to find new ideas. It is found by Miftah (2010) who stated that, "By implementing mind mapping with the proper models developed, the students' ability in writing descriptive text improves". Besides, Nurlaila (2013) also studied about mind mapping in the learning of writing. She found that mind mapping was successful to improve the students' vocabulary and creativity to organize sentences and ideas in the learning of writing. Moreover, Mahmud, Rawshon, and Rahman (2011) found that the use of mind mapping for academic writing at university enhanced the learning of writing and could generate the ideas. In other words, mind mapping is an important way to generate and improve the idea in learning writing skill at university. Therefore, this research would like to investigate students' perception on the use of mind mapping application software in learning writing; and to describe the advantages and disadvantages of using mind mapping application software in learning writing. in short there are numerous of research questions, as follows;

\section{METHOD}

The design of the research was mixed method. Quantitative analisis used to investigate the students' perception on the use of mind mapping application software in learning writing. While the qualitative analysis is applied to describe the advantages and disadvantages on the use of mind mapping application software in learning writing. In order to collect the data, the researcher used questionnaire and interview as the technique. In addition, the researcher employed two instruments. They were questionnaire and interview guide.

In this research, the subjects of the study were students' in class B who joined writing 4 in academic year 2014 at English Language Education Department in a university in Malang, East Java. They were selected as the research subject because the class used mind mapping application software in learning writing.

CELTIC: A Journal of Culture, English Language Teaching, Literature \& Linguistics 


\section{FINDINGS AND DISCUSSION}

\section{Findings}

The researcher presents the findings of this study. It was about (1) the students' perception on the use of mind mapping application software, (2) the advantages and (3) the disadvantages of using mind mapping application software used by the teacher in learning writing.

\section{Students' Perception on Using Mind Mapping Application Software in Learning Writing}

Based on the result of the data analysis, it was found that there was positive and negative perception on the use of Mind Mapping application software in learning writing.

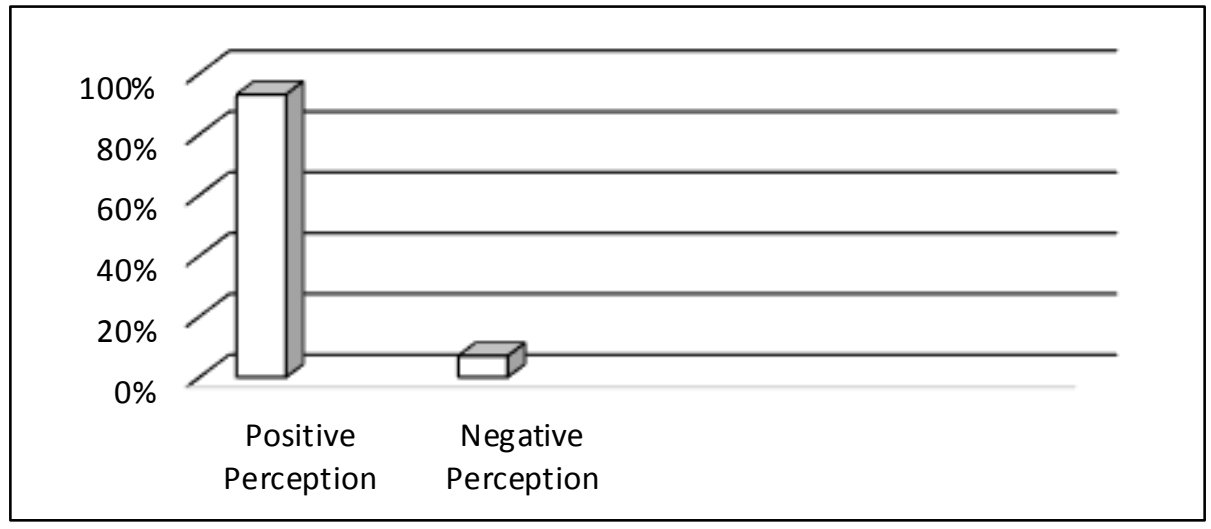

Table 3 Students Perception

It was found that out of 23 students, 21 students (93\%) had positive perception on the use of mind mapping application software in learning writing. On the other hand, there were 2 students (7\%) had negative perception on the use of mind mapping application software. Thus, the majority of the students (93\%) asserted that the use of mind mapping application software in learning writing was very good for them and helped them in learning writing.

\section{The Advantages on Using Mind Mapping Application Software in Learning Writing}

Based on the result of data analysis, it was found that the first advantage of mind mapping application software was easy to use in learning writing. This finding is supported by the respondents who stated that Mind Mapping eased the students to think and organize their ideas before writing something. Moreover, Mind Mapping made the students' writing more well-structured.

CELTIC: A Journal of Culture, English Language Teaching, Literature \& Linguistics 
"It makes me more easier and more make my writing little bit challenging because even though the topic is hard I can organize the idea easier" (R 3/L42, R4/L13, R5/L11)

The second advantage of mind mapping application software was that it facilitated students develop or organize their idea. This was because mind mapping led the students to arrange their ideas in more detail. Besides, the respondents stated that mind mapping helped them organize the ideas and know the steps where they should start their writing. In addition, developing or organizing the ideas could make their writing coherent.

\footnotetext{
"It helps me in learning of writing and I think with mind mapping we can enjoy and more easily to make a paragraph" (R2/L13).
}

"It makes me to be creative because forces me to arrange the idea and also force me to arrange more detail of idea" (R3/L43).

The last advantage of using mind mapping application software was that it helped the students remember better about the ideas. For example, before the students started to write, they should make the centre of the topic and put the ideas into the right branches. When the students forget some ideas that should be written on their paper, Mind Mapping could help them remember the ideas; in other words, it also became a good reminder for them.

"If we write something which is come to our brain we often get lost and forget what we want to write. By looking again (to Mind Mapping), the first point is this, it will be become good reminder for us to writing again (R4/L23).”

\section{The Disadvantages on Using Mind Mapping Application Software in Learning Writing}

Based on the result of data analysis, it was found that the first disadvantage of mind mapping application software was that it took a longer time for the students to finish their writing. This finding was supported by the respondents who thought that mind mapping application software used by the teacher took a longer time in organizing and finding an effective keyword. This was because it more complicated for the students. For example, when the students wanted to put or add some ideas, they should drag the mouse to the other side, then they added into branches, it makes the students' take longer time.

"The disadvantage of mind mapping I think we take a long time around one hours or more to think the idea and also to make a mind mapping (R2/L35, R3/L37, R4/49).”

The other disadvantage, the use of mind mapping application software needs computer access which makes the students feel complicated. For example, when the students want to create mind mapping, automatically they needed computer access that had already installed the mind mapping application software to open and to create it.

CELTIC: A Journal of Culture, English Language Teaching, Literature \& Linguistics 
"when I want to open the mind map, but I don't have the software mind mapping then I cannot access the mind mapping. So that I have to open to laptop that already installed the software (R4/43)."

\section{Discussion}

The research finding proved that the $6^{\text {th }}$ semester students in B class of writing had positive perception toward the used of mind mapping application software in learning writing. The most of the students answered strongly agree and agree on using mind mapping application software in learning writing. In other words, the students perceive that mind mapping help them in learning writing. This finding in line with Irwanto (2002) stated that Positive perception is perception that describes all information and respond object that perceived positively. Then, the students that answered disagree which means they had negative perception on the use of mind mapping application software in learning writing. The finding in line with Irwanto (2002) stated that negative perception is perception that describes all information negatively or not suitable with the object that perceived.

Related to the answer of the students, it showed that mind mapping gave some advantages for the students'. This proved by the good answer from the students about the use of mind mapping application software. Firstly, mind mapping application software eased the students to think and organize their ideas before writing something. Secondly, it facilitated the students to develop their idea. Thirdly, it helped the students remember better about the ideas or became good reminder when the students forget about their ideas. The findings above were in line with Buzan (2005) stated that mind mapping gives the advantages to the user in remembering better on something, making batter notes, arise with brilliant ideas, organize our thinking and have more fun in learning process. In addition, Murley (2007) also stated that mind mapping has several advantages, they are; the design keeps the main topic, the connection of the main topic and sub topic easy to see in the mind mapping, it encourages creativity, easier to understand, and increase productivity in learning. Therefore, Mind Mapping gave many advantages to the students in learning process.

The next discussion was about the disadvantages on the use of mind mapping application software in learning writing. Based on the finding, the most of the students' stated creating mind mapping took a longer time because they should think the ideas and write down the ideas into branches in which the ideas should be related to the main topic. The disadvantage above was relevant with previous study which conducted by Nurlaila (2013) when the students create a mind mapping, they need a longer time to finish their writing because, their more focused on write down the ideas to their maps instead of focus on their structure of writing.

CELTIC: A Journal of Culture, English Language Teaching, Literature \& Linguistics

ISSN: 2356-0401, E-ISSN: 2621-9158, VOL. 6, NO. 1, June 2019. 
The next disadvantage based on the finding was the students' thought the used of mind mapping application software needed computer access to create and open mind mapping which makes the students little bit complicated to used it. This finding in line with Tucker, Amstrong and Massad (2010) stated that disadvantages of using mind mapping application software are always requires computer access and restricted incompatibility format.

\section{CONCLUSIONS AND SUGGESTION}

The researcher drew the conclusion based on the research findings. The first finding was related to the first research problem about the students' perception on the use of mind mapping application software in learning writing. Then, the second and third findings were related to the advantages and disadvantages on the use of Mind Mapping application software in learning writing.

According to the students' perception on the use of mind mapping application software, there were positive and negative perception on the use of Mind Mapping application software in learning writing. Meanwhile, the majority of the students had positive perception on the use of mind mapping application software in learning writing and they perceived that mind mapping application software is an effective tool to help them to organize the ideas in learning writing.

In addition, the use of mind mapping application software in learning writing gave three advantages, namely; (1) Mind Mapping application software eased the students to organize their ideas before writing something; (2) it facilitated the students to develop their ideas; and (3) it helped the students remember better about the ideas.

On the contrary, mind mapping application software also gave two disadvantages in learning Writing. The disadvantages were: (1) it took longer time to create and organize the ideas; and (2) it needed computer access to create Mind Mapping.

\section{REFERENCES}

Adelabu, B. (2013). Constraints of English Language Teaching and Learning in Benue State Secondary Schools. International Journal of Innovative Research and Development., 396-401.

Arikunto, S. (2013). Procedur Penilitian: Suatu Pendekatan Praktik. Jakarta : Rineka Cipta.

Ary, D., Jacob, Sorensen, \& Razavieh. (2010). Introduction to Research in Education. Canada: Wadsworth Cangage Learning.

CELTIC: A Journal of Culture, English Language Teaching, Literature \& Linguistics

ISSN: 2356-0401, E-ISSN: 2621-9158, VOL. 6, NO. 1, June 2019. 
Brown, H. D. (2000). Teaching by Principles: An Interactive Approach to Language Pedagogy. California: Pearson Education.

Buzan, T. (2005). Mind Maps for Kids: An Introduction the Shortcut to Success at School. United Kingdom: Thorsons.

Buzan, T. (2012). The Ultimate Book of Mind Maps: Unlock Your Creativity, Boost Your Memory, Change Your Life. United Kingdom: Harper Collins.

Hallen, D., \& Sangeetha, N. (2015). Effectiveness of Mind Mapping in English Teaching Among VIII Standard Students. I-manager's Journal on English Language Teaching, 45- 50.

Harmer, J. (1998). How to Teach English: an introduction to the practice of English Language Teaching. England: Longman.

Irwanto. (2002). Psikologi Umum. Jakarta: PT. Prenhallindo

Kuihara, S. A., Hawken, L. S., \& Graham, S. (2009). Teaching Writing to High School Students: A National Survey. Journal of Education Psychology, 136-160.

Kusmiana, L. (2013). Guided Writing Activities in Teaching Writing to Seventh Grade Students of Mtsn Watulimo Trenggalek. Lingua Scientia, 191-198.

Mahmud, I., Rawshon, S., \& Rahman, M. J. (2011). Mind Map for Academic Writing: A Tool to Facilitate University Level Student. International Journal of Educational Science and Research, 21-30. .

Miftah, Z. M. (2010). Improving the Tenth-Year Students Writing Ability at MA Mambaus Sholihin Gresik Through Mind Mapping. Lingua Jurnal Ilmu Bahasa dan Sastra, 178-181.

Murley, D. (2007). Mind Mapping Complex Information. Law Library Journal, pp. 175-183.

Muslim, I. M. (2014). Helping EFL Students Improve their Writing. International Journal of Humanities and Social Science, 105-112.

Nurlaila, A. P. (2013). The Use of Mind Mapping Technique in Writing Descriptive Text. Journal of English and Education, 9-15.

Tucker, M. J., Armstrong, G., \& Massad, V. (2010). Profiling a Mind Map User: A Descriptive Appraisal. Journal of Instructional Pedagogies, 1-13.

CELTIC: A Journal of Culture, English Language Teaching, Literature \& Linguistics ISSN: 2356-0401, E-ISSN: 2621-9158, VOL. 6, NO. 1, June 2019. 